\title{
Peran Dan Tanggung Jawab Notaris Dalam Memperoleh Surat Keterangan Wasiat Terkait Permohonan Oleh Ahli Waris
}

\author{
Anak Agung Devyn Amanda Dhiyo', I Wayan Wiryawan² \\ 1Fakultas Hukum Universitas Udayana, E-mail: devynamanda@gmail.com \\ 2Fakultas Hukum Universitas Udayana, E-mail: wayan_wiryawan@yahoo.com
}

\begin{abstract}
Info Artikel
Masuk: 20 April 2020

Diterima : 28 April 2020

Terbit : 1 April 2021

Keywords :

wills, notaries, heirs

Kata kunci:

Wasiat, Notaris, Ahli waris

Corresponding Author:

Anak Agung Devyn Amanda

Dhiyo, E-mail:

devynamanda@gmail.com

DOI :

10.24843/AC.2021.v06.i01.p13
\end{abstract}

\begin{abstract}
This writing aims to determine the role and responsibility of the notary in obtaining a will. The author uses empirical research methods with a fact approach and primary data along with secondary data. The result of the research shows that the role and responsibility of the Notary Public in obtaining a will is to apply for a will. If there is a will made by the deceased based on the statement obtained, the notary is responsible for reading the contents of the will, in addition to being the party authorized to read the will, the notary is also the middle party to calm and provide an explanation if questions arise by the heirs.
\end{abstract}

\section{Pendahuluan}

\begin{abstract}
Abstrak
Penulisan ini bertujuan untuk mengetahui peran dan tanggung jawab Notaris untuk memperoleh surat keterangan wasiat. Penulis menggunakan metode penelitian empiris dengan pendekatan fakta dan data primer berikut data sekunder. Hasil penelitian menunjukkan bahwa peran dan tanggung jawab Notaris dalam hal memperoleh surat keterangan wasiat adalah melakukan permohonan surat keterangan wasiat. Apabila terdapat wasiat yang dibuat oleh Almarhum berdasarkan keterangan wasiat yang diperoleh maka Notaris bertanggung jawab untuk membacakan isi dari wasiat tersebut, selain menjadi pihak yang berwenang untuk membacakan wasiat tersebut, Notaris juga sebagai pihak tengah untuk menenangkan dan memberikan penjelasan apabila timbul pertanyaan oleh ahli waris.
\end{abstract}

Peristiwa penting sejak seseorang dilahirkan di dunia ini adalah pada waktu dilahirkan, pada waktu menikah dan pada waktu meninggal dunia, ketiga peristiwa penting ini dalam kehidupan manusia akan dilalui dalam berbagai proses yang dinamakan dengan proses kehidupan. Proses kehidupan manusia dilalui dengan menggunakan cara dan pemikiran yang berbeda, tidak setiap manusia mempunyai pemikiran sama untuk menjalani sebuah proses kehidupannya, 
karenanya itu terdapat proses kehidupan manusia yang baik dan yang buruk sehingga dapat menyebabkan hal-hal baik dan hal-hal yang buruk terjadi.

Hak dan kewajiban manusia di dunia ini telah diakui oleh Negara dengan bukti diundangkannya UUD RI 1945 dan UU No. 39 Th. 1999 tentang Hak Asasi Manusia, dengan adanya Hak Asasi Manusia, maka seseorang berhak untuk membuat surat wasiat yang didalamnya terkandung kemauan terakhir dari seseorang yang membuatnya, dan wasiat ini dapat dicabut kembali selama seseorang yang membuat wasiat ini masih hidup.

Masalah wasiat merupakan persoalan di dalam hukum perdata, adanya perbedaan yang signifikan antara hukum barat, adat di Indonesia, serta hukum islam dalam menyelesaikan wasiat. Bagi orang barat dalam menggunakan hartanya termasuk mewasiatkannya kepada siapapun, meskipun keluarga sama sekali tidak mendapatkan harta peninggalan. ${ }^{1}$

Wasiat merupakan salah satu bentuk atau cara untuk mengalihkan warisan, yang juga merupakan pesan terakhir dari seseorang sebelum ia meninggal, pesan yang dimaksud adalah tentang apa yang harus dilakukan oleh penerima wasiat terhadap harta yang ditinggal atau berupa pesan lain yang ditinggalkannya. Wasiat juga dikenal dengan nama lain "tasharruf"yakni diartikan sebagai pelepasan terhadap harta peninggalan yang harus dilakukan pada saat sesorang meninggal dunia, dan akan ditunjuk oleh surat wasiat tersebut untuk melaksanakan perintah wasiat tersebut. $^{2}$

Hukumnya wasiat merupakan suatu perbuatan yang dilakukan berdasarkan kemauan hati di dalam keadaan apapun, maka dari itu tidak disyaratkan oleh hukum dan wasiat tidak pernah dilakukan dengan jalan putusan hakim, karena wasiat merupakan sesuatu yang tidak diharuskan dibuat sebelum seseorang meninggal dunia, seseorang sebelum meninggal dunia membuat wasiat karena ada suatu permintaan dan pesan kepada penerima wasiat untuk menjaga harta peninggalannya. Kompilasi Hukum Islam memberikan pengertian mengenai wasiat yakni wasiat merupakan pemberian suatu benda dari pewaris kepada orang lain atau lembaga yang akan berlaku, setelah pewaris meninggal dunia, sebagaimana telah ternyata di dalam KHI Pasal 171 huruf f, pemberian suatu benda kepada pewaris bisa diartikan bahwa pelimpahan tanggung jawab kepada pewaris agar bisa mewarisi dan menjaga harta peninggalannya. ${ }^{3}$

KUHPerdata (BW) telah menguraikan di dalam norma yakni bentuk-bentuk wasiat dibagi menjadi 4 (empat) yaitu :

\section{Pasal 937 KUHPerdata}

\footnotetext{
${ }^{1}$ Hadi, S. (2017). Pembatasan Wasiat Sebagai Bentuk Keadilan Hukum Islam. Al-Ahwal: Jurnal Hukum Keluarga Islam, 9(2), 169-184. hal. 169

${ }^{2}$ Basyir, A. A. (1995). Hukum Waris Islam. Bagian Penerbitan Fakultas Ekonomi, Universitas Islam Indonesia. hal. 45

3Syarifuddin, A. (2004). Hukum Kewarisan Islam. Kencana. hal. 50
} 
Menerangkan bentuk wasiat yakni berbentuk wasiat umum yang telah dibuat di hadapan Notaris dan dihadiri oleh 2 (dua) orang saksi, membuat wasiat dalam bentuk umum paling sering dilakukan oleh seseorang, karena surat wasiat akan disimpan dengan baik oleh Notaris, dan akan dilaksanakan dan dibacakan oleh Notaris setelah seseorang pembuat wasiat tersebut meninggal dunia.

\section{Pasal 931 KUHPerdata}

Menerangkan bentuk wasiat yakni berbentuk olographis, yaitu wasiat seluruhnya telah ditulis oleh calon pewaris dan telah dibubuhi tanda tangan olehnya, dengan ini peran Notaris hanya membuatkan akta penyimpanan atau Depot untuk menyimpan tulisan wasiat tersebut.

3. Pasal 940 KUHPerdata

Bila pewaris hendak membuat surat wasiat tertutup atau rahasia, dia harus menandatangani penetapan-penetapannya.

4. Pasal 946, 947, 948 KUHperdata

Menerangkan bentuk wasiat bersifat darurat yang hanya dibuat oleh tentara dalam keadaan perang, seseorang yang berada di dalam pelayaran, yang berada di dalam karantina karena mengidap penyakit menular.

Seseorang yang berhak membuat wasiat dan menunjuk seseorang sebagai pewaris ialah seseorang yang diatur di dalam Kompilasi Hukum Islam, selanjutnya disingkat dengan KHI, yakni, pemberi wasiat di dalam Pasal 194 KHI pada ayat (1) adalah orang yang telah berumur sekurang-kurangnya 21 (dua puluh satu) tahun, mempunyai akal sehat dan tidak menerima paksaan dari pihak manapun, dan dapat mewasiatkan sebagian harta bendanya kepada seseorang atau lembaga. Harta benda yang dimaksud adalah harta yang merupakan hak dari pemberi wasiat tersebut, contohnya adalah mempunyai atas nama dalam harta benda tersebut, dan memiliki harta benda dari pemberi wasiat baru bisa dilakukan jika pemberi wasiat telah meninggal dunia. ${ }^{4}$

Pemberi wasiat memiliki kriteria berdasarkan KUHPerdata dalam Pasal 856 haruslah mempunyai akal sehat yakni tidak sedang mengalami sakit berat dan membuat tidak bisa berpikir secara wajar, karena apabila pemberi wasiat dalam keadaan sakit berat apa yang telah ditulis di dalam wasiat dianggap tidak benar dan tidak wajar, dalam hal ini pembuatan surat wasiat haruslah di hadapan pejabat yang berwenang agar memiliki kepastian hukum dikemudian harinya. ${ }^{5}$

Aturannya surat wasiat dibuat di hadapan pejabat yang berwenang, pejabat yang berwenang adalah Notaris, Notaris adalah pejabat umum yang mempunyai kewenangan untuk membuat akta otentik, sebagaimana telah dinyatakan di dalam Pasal 1 UU No. 2 Th. 2014 sebagai pengganti dari UU No. 30 Th. 2004 mengenai Jabatan Notaris, selanjutnya disebut dengan UUJN. Notaris berwenang membuat akta otentik, Pasal 1868 KUHPerdata menyatakan bahwa "Suatu akta otentik ialah suatu

\footnotetext{
${ }_{4}^{4}$ Abdullah, A. G. (1994). Pengantar Kompilasi Hukum Islam dalam Tata Hukum Indonesia. Gema Insani. hal. 30

5 Annisa, A., Rinaldi, Y., \& Abdurahman, T. (2019). Tanggung Jawab Notaris Yang Tidak Mendaftarkan dan Melaporkan Akta Wasiat Ke Daftar Pusat Wasiat. Syiah Kuala Law Journal, 3(1), 1-17.hal. 2
} 
akta yang dibuat dalam bentuk yang ditentukan undang-undang oleh atau dihadapan pegawai-pegawai umum yang berkuasa untuk itu, di tempat dimana akta itu dibuat".

Ketika seseorang sebelum meninggal dunia membuat surat wasiat dihadapan Notaris, maka

seseorang tersebut meminta kepada Notaris untuk menuangkan kehendaknya ke dalam akta wasiat, dan akan ditandatangani oleh pembuat wasiat. Setelah ditandatangani maka surat Wasiat akan disimpan dengan baik oleh Notaris dan akan dilaksanakan setelah pembuat wasiat meninggal dunia. Pendaftaran surat wasiat dilakukkan oleh Notaris kepada Pusat Daftar Wasiat, hal ini untuk membuktikan bahwa semasa hidupnya almarhum telah ada dan atau dapat membuat wasiat.

Pusat Daftar Wasiat merupakan suatu lembaga yang disediakan oleh Kementerian Hukum dan Ham RI melalui situs Direktorat Jenderal AHU untuk layanan bagi Notaris yang akan mendaftarkan akta wasiat tersebut dan memperoleh tanggal daftar wasiat pada pusat daftar wasiat, hal ini dilakukan karena untuk dapat mengetahui nantinya almarhum pada masa hidupnya ada atau tidak membuat wasiat. Seseorang yang bergolongan darah tionghoa pada umumnya lebih banyak membuat akta wasiat daripada golongan lainnya, ini salah satu pemikiran manusia yang berbeda dalam proses kehidupannya.

Berdasarkan penjelasan di atas maka ditemukan suatu rumusan masalah yaitu bagaimana peran dan tanggung jawab Notaris dalam hal memperoleh surat keterangan wasiat terkait permohonan ahli waris. Tujuan penelitian ini adalah untuk mengetahui peran dan tanggung jawab Notaris dalam hal memperoleh surat keterangan wasiat terkait permohonan ahli waris.

Pentingnya peran surat wasiat dalam pelaksanaanya yakni menunjuk penerima wasiat dan pengalihan harta benda, maka dalam jurnal ini penulis ingin melakukan penelitian dan mengangkat judul penelitian yaitu "Peran dan Tanggung Jawab Notaris Dalam Hal Memperoleh Surat Keterangan Wasiat Terkait Permohonan Ahli Waris".

Sebelumnya terdapat penelitian yang berjudul "Kedudukan Wasiat Dalam Pembuatan SKW" karangan W Andriawan yang membahas tentang kedudukan wasiat dan kewenangan notaris dalam penerbitan surat keterangan wasiat ${ }^{6}$ dan penelitian yang berjudul "Kekuatan Hukum Surat Wasiat Yang Dibuat Dihadapan Notaris Terhadap Anak Angkat Pada Harta Warisan Orang Tua" karangan Adek Dwitama yang membahas tentang kekuatan hukum surat wasiat terhadap hak anak angkat pada harta warisan orang tua dan untuk mengetahui kendala-kendala dalam pelaksanaanya. ${ }^{7}$ Kedua tulisan tersebut memiliki perbedaan kajian dengan tulisan ini karena tulisan ini mencoba menganalisa mengenai peran dan tanggung jawab Notaris dalam hal memperoleh surat keterangan wasiat terkait permohonan ahli waris.

\footnotetext{
${ }^{6}$ Andriawan, W. (2019). Kedudukan Wasiat Dalam Pembuatan Skw (Doctoral dissertation, Universitas Airlangga). hal. 5

7 DWITAMA, A. K. (2016). Kekuatan Hukum Surat Wasiat Yang Dibuat Dihadapan Notaris Terhadap Anak Angkat Pada Harta Warisan Orang Tua (Doctoral dissertation, Universitas Muhammadiyah Palembang).hal. 6
} 


\section{Metode Penelitian}

Sesuai dengan judul artikel ini, maka digunakan penelitian hukum empiris, yakni melakukan penelitian di lapangan terkait untuk mengetahui peran dan tanggung jawab Notaris dalam hal memperoleh surat keterangan wasiat terkait permohonan ahli waris, pendekatan yang dilakukan adalah mencari fakta di tempat terkait mengenai surat wasiat, pendaftaran wasiat, dan pelaksanaan wasiat yang telah dimohonkan oleh ahli waris pembuat wasiat. Teknik wawancara akan dilakukan langsung kepada Notaris.

\section{Hasil Dan Pembahasan}

\subsection{Peran Notaris Dalam Memperoleh Surat Keterangan Wasiat Yang Pernah Dibuat Oleh Almarhum}

Testamen atau dikenal dengan surat wasiat adalah akta yang di dalamnya telah tertuang sebuah pernyataan yang dikehendaki akan terjadi sebelum seeorang meninggal dunia, yang bilamana mana atas kehendaknya juga wasiat ini bisa dicabut kembali olehnya, pencabutan wasiat yang dimaksud hanya bisa dilakukan bilamana seseorang tersebut belum meninggal dunia. ${ }^{8}$ Seseorang yang membuat wasiat dalam hidupnya telah memikirkan dan memastikan kepada siapa yang ditunjuk untuk mengurus dan menerima pewarisan harta benda yang dimiliki seseorang tersebut di masa hidupnya, karena di dalam surat wasiat tidak ditentukan bahwa ahli warislah yang akan ditunjuk, melainkan bisa teman semasa hidup, ataupun kepada orang kepercayaan. ${ }^{9}$

Berdasarkan bentuk-bentuk wasiat yang telah dijelaskan di atas, maka pada umumnya bentuk wasiat yang telah dinyatakan di dalam Pasal 938 KUPerdata paling sering dilakukan, mengingat akan kepercayaan masyarakat terhadap jasa Notaris yang bisa memberikan kebutuhan hukum, pelayanan hukum dan kepastian hukum. Pembuatan akta wasiat oleh Notaris dilakukan dengan cara atau proses sebagai berikut :10

1. Pihak yang akan membuat wasiat akan mengunjungi Notaris selaku pejabat yang berwenang untuk membuat akta otentik, mengutarakan kehendaknya kepada Notaris untuk dituangkan ke dalam akta wasiat, menunjuk nama salah seorang ahli waris untuk menjalankan isi perintah wasiat tersebut;

2. Harta benda yang nantinya akan diwariskan haruslah dimasukkan ke dalam akta wasiat;

3. Minuta akta wasiat akan ditandatangani oleh pembuat wasiat;

4. Penandatanganan akta wasiat ini dihadiri oleh dua orang saksi;

8 Sanjaya, U. H. (2018). Kedudukan Surat Wasiat Terhadap Harta Warisan Yang Belum Dibagikan Kepada Ahli Waris. Jurnal Yuridis, 5(1), 67-97. hal. 22

9 Annisa, A., Rinaldi, Y., \& Abdurahman, T. (2019). Tanggung Jawab Notaris Yang Tidak Mendaftarkan dan Melaporkan Akta Wasiat Ke Daftar Pusat Wasiat. Syiah Kuala Law Journal, 3(1), 1-17. hal. 5

10 Prastuti, M.T.M. (2006). Peran dan Tanggungjawab Notaris Atas Akta Wasiat (Testament Acte) Yang Dibuat Dihadapannya (Doctoral dissertation, program Pascasarjana Universitas Diponegoro). hal. 125 
5. Minuta akta wasiat akan disimpan baik oleh Notaris untuk dikemudian dibacakan setelah pembuat wasiat meninggal dunia;

6. Sebelum pembuat wasiat meninggal dunia diperbolehkan untuk mencabut kembali wasiat tersebut.

Seorang ahli waris adalah dia yang menjadi pewaris harta benda peninggalan seseorang, dalam wasiat, ahli waris tidak hanya keturunan yang lahir dari pembuat wasiat, melainkan juga bisa teman dan orang kepercayaan yang bisa menjadi ahli waris, namun pembuatan akta wasiat jarang diketahui oleh ahli waris dikarenakan akta wasiat ini bersifat rahasia, dalam artian hanya yang pembuat wasiat dan Notaris yang mengetahuinya. ${ }^{11}$ Tanpa sepengetahuan ahli waris terhadap akta wasiat yang pernah dibuat, membuat ahli waris akan mengunjungi Notaris untuk melakukan permohonan surat keterangan waris dengan tujuan untuk mengetahui seseorang tersebut pernah atau tidak membuat wasiat.

Permohonan keterangan waris dilakukan oleh ahli waris pada umumnya pihak keluarga untuk mengetahui adanya wasiat atau tidak atas nama almarhum, permohonan keterangan waris bisa dilakukan oleh Notaris yang telah mempunyai akses untuk melakukan permohonan ke Pusat Daftar Wasiat. Berikut beberapa peran Notaris dalam melakukan permohonan surat keterangan wasiat, adalah :12

1. Notaris membuat minuta akta wasiat berdasarkan kehendak seseorang sebelum meninggal dunia;

2. Menuangkan seluruh kehendak seseorang dan di dalam akta tersebut telah dimasukkan nama ahli waris selaku yang telah ditunjuk di dalam akta;

3. Minuta akta wasiat ditandatangani diatas materai oleh seseorang pembuat wasiat ;

4. Minuta akta telah disimpan dengan baik oleh Notaris, agar bisa melakukan pembacaan wasiat di waktu yang telah tiba;

5. Setelah seseorang tersebut meninggal dunia, maka ahli waris akan melakukan permohonan surat keterangan waris di kantor Notaris yang berwenang;

6. Notaris akan mengajukan permohoan surat keterangan waris pada portal Dirjen AHU dengan memasukkan tanggal dan nomor akta;

7. Surat keterangan waris akan dikeluarkan oleh daftar pusat wasiat, lalu oleh Notaris dapat mendownloadnya;

8. Surat keterangan waris akan menerangkan bahwa almarhum ada atau tidak membuat wasiat.

Mengenai hal tersebut maka terhadap permohonan ahli waris kepada Notaris dalam hal permohonan surat keterangan wasiat biasanya ahli waris akan mempunyai tujuan untuk melakukan turun waris akibat meninggalnya seseorang. Sebelum melakukan turun waris, akan dilakukan terlebih dahulu pengecekan ke daftar pusat wasiat untuk dapat memastikan bahwa ada atau tidaknya almarhum semasa hidupnya membuat

${ }^{11}$ Adriawan, A. (2013). Pelaksanaan Wasiat Menurut KUH Perdata di Pengadilan Negri Makassar (Di Tinjau dari Kompilasi Hukum Islam) (Doctoral dissertation, Universitas Islam Negeri Alauddin Makassar). hal. 15

12 Yustiningsih, A. J. (2009). Kajian Terhadap Peranan Notaris Dalam Pembuatan Dan Pencabutan Testamen Di Kota Semarang (Doctoral dissertation, Program Pascasarjana Universitas Diponegoro). hal. 165 
wasiat. Jika terdapat almarhum semasa hidupnya membuat wasiat maka akan dilaksanakan terlebih dahulu pembacaan wasiat kepada ahli waris agar dapat mengetahui apa yang menjadi kehendak almarhum sebelum ia meninggal dunia. Situasi yang sering terjadi pada saat wasiat dilaksanakan adalah sering munculnya keributan akibat ada yang merasa tidak adil atas pelimpahan harta benda yang dituangkan di dalam wasiat, seringkali terjadi keributan dalam membacakan isi wasiat, hal buruk ini tidak dapat dipungkiri karena bagaimanapun suatu hal yang menyangkut harta benda sangatlah sensitif. Apabila wasiat telah dapat diterima oleh para ahli waris, dan ahli waris yang ditunjuk di dalam wasiat, maka Notaris akan menerbitkan surat keterangan wasiat berdasarkan wasiat tersebut.

Berdasarkan hak tersebut maka Notaris sangatlah berperan dalam melakukan permohonan surat keterangan wasiat, karena hanya Notaris yang mempunyai akses untuk melakukan permohonan surat keterangan wasiat, dan Notaris juga berwenang untuk menerbitkan surat keterangan wasiat tersebut.

\subsection{Tanggung Jawab Notaris Apabila Terdapat Wasiat Yang Dibuat Oleh Almarhum Berdasarkan Keterangan Wasiat Yang Diperoleh}

Kewenangan Notaris dalam membuat akta otentik adalah bersifat formil dan materiil, kebenaran formil dari akta adalah merupakan bentuk tanggung jawab dari Notaris, namun disamping itu Notaris juga mampu membuktikan tanggung jawabnya secara materiil yang artinya kebenaran materiil mampu membuktikan bahwa terjadinya kelalaian yang tidak disengaja yang dilakukan oleh Notaris, tanggung jawab dalam kebenaran materiil, dibagi menjadi :13

1. Tanggung jawab Notaris dalam bentuk perdata akan kebenaran materiil terhadap akta yang dibuatnya;

2. Tanggung jawab Notaris dalam bentuk pidana akan kebenaran materiil terhadap akta yang dibuatnya;

3. Tanggung jawab Notaris berdasarkan UUJN akan kebenaran materiil terhadap akta yang dibuatnya;

4. Tanggung jawab Notaris berdasarkan Kode Etik Notaris;

Dengan adanya kewenangan dan kewajiban Notaris yang diatur di dalam UUJN, maka timbullah suatu tanggung jawab yang akan dipikul oleh Notaris, namun hal ini timbul dari adanya pelanggaran atas kelalaian dan kesengajaan yang dilakukan oleh Notaris terhadap akta yang dibuatnya apabila dikemudian hari dapat menimbulkan masalah dan batal demi hukum. ${ }^{14}$

Akta wasiat yang dibuat di hadapan Notaris juga menjadi tanggung jawab Notaris, meskipun tidak terdapat kesalahan dan kelalaian yang dibuat oleh Notaris terhadap akta wasiat tersebut, namun tanggung jawab Notaris adalah kelak dikemudian hari membacakan isi wasiat tersebut di hadapan seluruh ahli waris. Pembacaan wasiat merupakan pelaksanaan wasiat itu sendiri dengan menunjuk ahli waris yang ditunjuk di

\footnotetext{
${ }^{13}$ Anshori, A. G. (2009). Lembaga kenotariatan Indonesia: perspektif hukum dan etika. UII Press.p. 16

14 Suniayasa, A. W., Sumardika, I. N., \& Astiti, N. G. K. S. (2020). Kewenangan Notaris dalam Pembuatan/Pencabutan Surat Wasiat (Testament). Jurnal Preferensi Hukum, 1(2), 6-10. hal. 7
} 
dalam akta wasiat tersebut dan mengusahakan agar keadaan dan situasi pada waktu membacakan wasiat berlangsung aman dan diterima baik oleh semua ahli waris. ${ }^{15}$

Mengenai hal tersebut, maka dilakukan wawancara dengan Bapak Notaris Jefriey Firmanyo Soegianto, SH,M.Kn tentang tanggung jawab Notaris apabila terdapat wasiat yang dibuat oleh Almarhum berdasarkan keterangan wasiat yang diperoleh, yakni sebagai berikut :

Pada waktu meninggalnya seseorang, oleh ahli warisnya akan mencari dan datang ke Notaris untuk menanyakan apakah almarhun pernah atau tidak membuat wasiat, dengan menjalankan tugas atas perintah UUJN, maka Notaris akan memberikan pelayanan hukum dengan melakukan permohonan ke daftar pusat wasiat, dalam pusat daftar wasiat akan tertera almarhum pernah atau tidak membuat wasiat, jika pernah akan terlihat pada Notaris siapa almarhum membuatnya. Tanggung jawab yang diberikan oleh Notaris apabila terdapat wasiat yang dibuat oleh almarhum adalah, sebagai Notaris yang berwenang yang membuat minuta akta wasiat akan membacakan isi dari wasiat tersebut, selain menjadi pihak yang berwenang untuk membacakan wasiat tersebut, Notaris juga sebagai pihak tengah untuk menenangkan dan memberikan penjelasan apabila timbul pertanyaan oleh ahli waris. (wawancara tanggal 13 April 2020, bertempat di Kantor Notaris Jefriey Firmanyo Soegianto, SH,M.Kn, Jalan Diponegoro (Pertokoan Genteng Biru/IDT) Denpasar-Bali)

Berdasarkan hasil wawancara di atas, maka tanggung jawab Notaris adalah berlangsung dari awal pembuatan akta wasiat hingga wasiat tersebut dibacakan, dalam hal ini hak dan kewajiban yang telah diatur di dalam UUJN telah melahirkan tanggung jawab yang harus dilaksanakan oleh Notaris dalam hal memberikan kepastian hukum akibat dari perbuatan hukum seseorang.

\section{Kesimpulan}

Peran dan tanggung jawab Notaris dalam hal memperoleh surat keterangan wasiat adalah melakukan permohonan surat keterangan wasiat. Hal ini dikarenakan hanya Notaris yang mempunyai akses untuk melakukan permohonan surat keterangan wasiat, dan Notaris juga berwenang untuk menerbitkan surat keterangan wasiat tersebut. Tanggung jawab Notaris apabila terdapat wasiat yang dibuat oleh Almarhum berdasarkan keterangan wasiat yang diperoleh adalah Notaris bertanggung jawab untuk membacakan isi dari wasiat tersebut, selain menjadi pihak yang berwenang untuk membacakan wasiat tersebut, Notaris juga sebagai pihak tengah untuk menenangkan dan memberikan penjelasan apabila timbul pertanyaan oleh ahli waris. Saran yang dapat diberikan adalah untuk menjaga harta benda yang telah dimiliki semasa hidup baiknya memang dibuatkan wasiat kepada ahli waris yang dipercaya untuk menjaganya dengan meninggalkan pesan terakhir sebelum meninggal dunia. Pembuatan wasiat disarankan dibuat dihadapan Notaris, karena wasiat bersifat rahasia dan akan terjaga aman di Notaris hingga nantinya dilaksanakan wasiat tersebut.

${ }^{15}$ Manik, A. N. (2021). Tanggung Jawab Hukum Notaris Dalam Pembuatan Dan Pendaftaran Surat Wasiat Secara Online Menurut Undang-Undang Nomor 2 Tahun 2014 Tentang Perubahan Atas Undang-Undang Nomor 30 Tahun 2004 Tentang Jabatan Notaris. Justitia: Jurnal Ilmu Hukum dan Humaniora, 7(4), 894-906. hal. 70 


\section{Daftar Pustaka / Daftar Referensi}

$\underline{\text { Buku }}$

Abdullah, A. G. (1994). Pengantar Kompilasi Hukum Islam dalam Tata Hukum Indonesia. Gema Insani

Anshori, A. G. (2009). Lembaga kenotariatan Indonesia: perspektifhukum dan etika. UII Press

Basyir, A. A. (1995). Hukum Waris Islam. Bagian Penerbitan Fakultas Ekonomi, Universitas Islam Indonesia.

Syarifuddin, A. (2004). Hukum Kewarisan Islam. Kencana.

\section{Jurnal}

Annisa, A., Rinaldi, Y., \& Abdurahman, T. (2019). Tanggung Jawab Notaris Yang Tidak Mendaftarkan dan Melaporkan Akta Wasiat Ke Daftar Pusat Wasiat. Syiah Kuala Law Journal, 3(1), 1-17.

Hadi, S. (2017). Pembatasan Wasiat Sebagai Bentuk Keadilan Hukum Islam. Al-Ahwal: Jurnal Hukum Keluarga Islam, 9(2), 169-184.

Manik, A. N. (2021). Tanggung Jawab Hukum Notaris Dalam Pembuatan Dan Pendaftaran Surat Wasiat Secara Online Menurut Undang-Undang Nomor 2 Tahun 2014 Tentang Perubahan Atas Undang-Undang Nomor 30 Tahun 2004 Tentang Jabatan Notaris. Justitia: Jurnal Ilmu Hukum dan Humaniora, 7(4), 894-906.

Sanjaya, U. H. (2018). Kedudukan Surat Wasiat Terhadap Harta Warisan Yang Belum Dibagikan Kepada Ahli Waris. Jurnal Yuridis, 5(1), 67-97.

Suniayasa, A. W., Sumardika, I. N., \& Astiti, N. G. K. S. (2020). Kewenangan Notaris dalam Pembuatan/Pencabutan Surat Wasiat (Testament). Jurnal Preferensi Hukum, 1(2), 6-10

\section{$\underline{\text { Disertasi }}$}

Adriawan, A. (2013). Pelaksanaan Wasiat Menurut KUH Perdata di Pengadilan Negri Makassar (Di Tinjau dari Kompilasi Hukum Islam) (Doctoral dissertation, Universitas Islam Negeri Alauddin Makassar).

Andriawan, W. (2019). Kedudukan Wasiat Dalam Pembuatan Skw (Doctoral dissertation, Universitas Airlangga).

DWITAMA, A. K. (2016). Kekuatan Hukum Surat Wasiat Yang Dibuat Dihadapan Notaris Terhadap Anak Angkat Pada Harta Warisan Orang Tua (Doctoral dissertation, Universitas Muhammadiyah Palembang). 
Prastuti, M.T.M. (2006). Peran dan Tanggungjawab Notaris Atas Akta Wasiat (Testament Acte) Yang Dibuat Dihadapannya (Doctoral dissertation, program Pascasarjana Universitas Diponegoro).

Yustiningsih, A. J. (2009). Kajian Terhadap Peranan Notaris Dalam Pembuatan Dan Pencabutan Testamen Di Kota Semarang (Doctoral dissertation, Program Pascasarjana Universitas Diponegoro

\section{$\underline{\text { Peraturan Perundang-Undangan }}$}

Kitab Undang-Undang Hukum Perdata (burgerlijk wetboek), dengan tambahan undangundang pokok agrarian dan undang-undang perkawinan, diterjemahkan oleh R.Subekti dan R. Tjitrosudibio, 2008, Cetakan 39, Pradnya Paramita.

Undang-Undang Negara RI, Undang-Undang No. 2 Th. 2014 tentang perubahan UndangUndang Negara RI, Undang-Undang No. 30 Th. 2004 tentang Jabatan Notaris (Lembaran Negara RI Th. 2014 No. 3 perubahan atas Lembaran Negara RI Th. 2004 No. 117 Tambahan Lembaran Negara 4432) 